\title{
An institutional perspective on the social outcome of entrepreneurship: Commercial microfinance and inclusive markets
}

\author{
Joshua K Ault
}

Peter B. Gustavson School of Business, University of Victoria, Victoria, BC, Canada

Correspondence:

JK Ault, Peter B. Gustavson School of Business, University of Victoria, 3800 Finnerty Drive, Victoria, BC, Canada V8P 5 C2.

Tel: (250) 472-5349;

email: jault@uvic.ca
Received: 9 March 2015

Revised: 15 February 2016

Accepted: 17 February 2016

Online publication date: 21 April 2016

\begin{abstract}
This study applies an institutional perspective to a current debate in social entrepreneurship about the relative effectiveness of commercial vs non-profit methods of building inclusive markets for the poor. While some observers argue that for-profit ventures are needed to serve the poor on a large scale, others express concern that commercialization causes mission drift, a phenomenon where ventures migrate to wealthier clients over time. A multilevel analysis of 2679 for-profit and non-profit microfinance lenders in 123 countries over 15 years supported the hypotheses that commercialization contributes to mission drift away from market inclusivity, but that national levels of "state fragility" moderate this effect. In countries with a low level of state fragility, it was less costly to serve the poor, which decreased pressure on commercial actors to shift to wealthier clients to achieve profitability. An important implication of this finding is that institutions influence not only the number of entrepreneurs found in a particular location but also the social impact of entrepreneurial strategies and actions.
\end{abstract}

Journal of International Business Studies (2016) 47, 951-967. doi:10.1057/jibs.2016.18

Keywords: international entrepreneurship; social entrepreneurship; inclusive markets; microfinance; state fragility

The online version of this article is available Open Access

\section{INTRODUCTION}

Scholars have recently identified a need for research that integrates the international entrepreneurship and social entrepreneurship literatures (Zahra, Newey, \& Li, 2014; Zahra, Rawhouser, Bhawe, Neubaum, \& Hayton, 2008). In their view, both bodies of literature have contributed important insights to our understanding of entrepreneurial motivation and performance, but gaps remain that could be addressed by integrating the findings of both fields. For instance, international entrepreneurship research has made inroads in describing how national institutions and cultures impact the entrepreneurial process (Busenitz, Gomez, \& Spencer, 2000; Jones, Coviello, \& Tang, 2011; McDougall \& Oviatt, 2000), but it typically focuses on financial measures of success, with less emphasis on the impact of entrepreneurial action on society. Social entrepreneurship research has explored the social implications of entrepreneurship (Dacin, Dacin, \& Matear, 2010; Mair \& Marti, 2006; Peredo \& McLean, 2006), but it tends to generalize its findings without 
considering national context. This divide between the two research streams has prompted calls for a new international social entrepreneurship approach that explores how national differences influence the social impact of new ventures (Zahra et al., 2014).

In response, this study applies an explicitly international perspective to a frequently debated issue in the social entrepreneurship literature: What are the longterm consequences of relying on commercial actors to advance the social goal of market inclusivity (Agafonow, 2014; London \& Hart, 2011; Prahalad, 2005; Santos, 2012)? "Market inclusivity" is the degree to which markets are able to engage and benefit individuals who are traditionally excluded, or even exploited, by current market systems - such as the poor, women, and other marginalized groups (George, McGahan, \& Jaideep, 2012; Mair, Marti, \& Ventresca, 2012; Mendoza \& Thelen, 2008; UNDP, 2010; USAID, 2014). Researchers from diverse fields not only social entrepreneurship but also base-of-thepyramid (London \& Hart, 2011; Prahalad, 2005), international development (Collier \& Dollar, 2002; Mendoza \& Thelen, 2008), and microfinance (CGAP, 2004) - have come to some consensus about the importance of inclusive markets as a tool to alleviate poverty. From this perspective, markets may be a powerful engine of economic growth and human development, but large populations remain excluded from their benefits. Thus a key priority of economic development is to extend market opportunities to larger segments of society. According to these researchers, entrepreneurs are central players in the creation and proliferation of any new market and are therefore critical to this initiative (Mendoza \& Thelen, 2008; UNDP, 2004).

Yet while academics and policymakers may agree on the benefits of inclusive markets in providing new opportunities for the poor, and the importance of entrepreneurs in this process, a debate still exists about which type of entrepreneurial venture is best suited to the task. Some observers maintain that forprofit firms should take the lead role in expanding inclusive markets since commercial organizations can more easily gather the resources necessary to spread innovations to the world's 4 billion poor citizens (London \& Hart, 2004, 2011; Prahalad, 2005). Others suggest that the cost and externalities of serving the poor may be too high to support a commercial model (Karnani, 2007; Santos, 2012). For-profit firms that try to pursue market inclusivity may feel pressure to migrate toward wealthier clients in order to generate higher revenue at less cost. Researchers often refer to this type of migration as "mission drift," which they identify as one of the primary risks of pursuing social goals using commercial methods (Battilana \& Dorado, 2010; Ebrahim, Battilana, \& Mair, 2014; Santos, Pache, \& Birkholz, 2015).

Some observers suggest that the debate about forprofit and non-profit solutions persists because we have limited empirical research on the long-term advantages and risks of relying on commercial actors to advance social goals (Agafonow, 2014; Kolk, RiveraSantos, \& Rufín, 2014; Walsh, Kress, \& Beyerchen, 2005). In their view, empirical support for each position is often based on individual case studies rather than on systematic data collection and analysis. These authors thus call for greater large-scale investigation to reconcile the social and commercial aspects of social entrepreneurship.

The current study contributes to this research agenda by empirically testing the relative ability of for-profit and non-profit ventures to reach the socially oriented goal of market inclusivity over time. Additionally, the article develops an international framework that adds a unique, multilevel perspective to the debate. International entrepreneurship research has demonstrated that all entrepreneurial actions are embedded in the sociopolitical environment where they take place (Bowen \& De Clercq, 2008; Busenitz et al., 2000; Casper \& Whitley, 2004; Jones et al., 2011; Spicer, McDermott, \& Kogut, 2000). I build on this insight to propose that national institutions may also shape the conditions that allow commercial agents to balance firm-level profitability objectives with the wider, societal goal of building inclusive markets.

To test this proposition, the current study develops a longitudinal, multilevel analysis of both the firmlevel effects of commercialization and the nationallevel effects of institutions on lending patterns in the global microfinance industry. Results support the hypothesis that national levels of "state fragility" influence the market inclusivity of entrepreneurial action. "State fragility" is the degree to which the state is unable and/or unwilling to fulfill core government functions for the majority of its people, including the poor (Ault \& Spicer, 2014). The analysis shows that commercial entrepreneurs are able to achieve desired social outcomes at low levels of state fragility, but donor-based non-profit models represent a better strategy for providing services to the poorest members of a community in states with a higher level of state fragility. The irony of this finding is that the most fragile states - which some scholars argue have the greatest need of for-profit 
ventures to generate market opportunities for the poor on a large scale (London \& Hart, 2011; Prahalad, 2005) - may present the biggest challenges when it comes to reaching a marginalized population through commercial models.

\section{SOCIAL ENTREPRENEURSHIP AND MISSION DRIFT}

Social entrepreneurship research on mission drift (Agafonow, 2015; Ebrahim et al., 2014; Ramus \& Vaccaro, 2014) provides an appropriate starting point for examining the potential benefits and risks of using commercial methods to advance market inclusivity. Mission drift is a phenomenon where the pursuit of profits causes socially oriented ventures to prioritize business objectives over development or social goals (Battilana \& Dorado, 2010; Battilana, Lee, Walker, \& Dorsey, 2012; Dees \& Anderson, 2003; Santos et al., 2015). In the study of business and poverty, market inclusivity is commonly used to identify the social impact of entrepreneurial action (George et al., 2012; Mair et al., 2012; Mendoza \& Thelen, 2008; Prahalad, 2005). Thus in this research, mission drift captures the extent to which an organization that has adopted the goal of market inclusivity deviates from this objective over time (Battilana \& Dorado, 2010; Santos et al., 2015).

International aid agencies suggest that markets are inclusive when they include the poor and other marginalized groups (e.g., women, youth, and indigenous people) on the demand side as clients and customers and on the supply side as employees, producers, and business owners (UNDP, 2010). However, they observe that the goal of market inclusivity may be difficult to achieve. Individuals at the base of the economic pyramid might desire certain products, and might be willing to pay for them if affordable options were available, but, for a variety of reasons, entrepreneurs are unwilling and/or unable to serve them (London \& Hart, 2011; Mair et al., 2012; Mendoza \& Thelen, 2008).

Recent efforts by the development community (UNDP, 2010, 2016) to increase market inclusivity in the global banking industry illustrate this scenario. Aid organizations have long recognized the importance of credit and other financial services for addressing the problem of global poverty. They have also noted that banks have historically struggled to make such products available to lower-income market segments. As Battilana and Dorado (2010) observe, lowincome clients can typically only afford small loans. However, banks often incur the same costs for a small loan as they do for a larger one, even though the small loan generates lower revenue with more risk. Thus traditional banks regularly avoid poorer populations, thereby excluding millions of low-income individuals from the benefits of the global financial market. In order to advance market inclusivity, some development agencies have started to promote entrepreneurial initiatives that improve the poor's access to affordable financial products. ${ }^{1}$ These initiatives focus primarily on microfinance but also include other innovations such as cell-phone money-transfer services and micro-insurance (UNDP, 2016).

Research on the relationship between business and poverty has begun to look at the potential benefits of using commercial actors to improve market inclusivity (Hart, 2005; London \& Hart, 2004, 2011; Prahalad, 2005). This research acknowledges that non-profit ventures have proven effective in the development of innovative business models to serve small numbers of customers in a single location. However, because extreme poverty afflicts 4 billion individuals roughly two-thirds of the world's population (Prahalad \& Hammond, 2002) - relying solely on non-profit organizations to advance market inclusivity may be unfeasible. Non-profit firms that depend on charitable donations are unlikely to reach the billions of individuals who live in poverty around the world. Since commercial agents can attract financial and human capital more easily than non-profits, the commercialization of innovative social models represents an important mechanism in building inclusive markets on a global scale (London \& Hart, 2011; Prahalad, 2005).

Yet Ebrahim et al. (2014) caution that introducing a profit motive into social organizations may not achieve this result. They suggest that when any organization adopts a commercial orientation independent of its stated mission, it is likely to become dependent on profits to satisfy shareholder expectations and pay for ongoing operations. This pressures the organization to prioritize its financial goals in order to ensure its survival. Since pursuing a social mission often generates less revenue (at greater cost and risk), a commercial venture may come to shift away from more socially oriented activities over time - or be forced out of business altogether.

Santos (2012) builds on the concepts of value creation and value capture to make a similar theoretical argument (see also Mizik \& Jacobson, 2003). In Santos' framework, commercial ventures maximize on value capture and satisfice on value creation; to do otherwise "can cause upheaval on stakeholders and may lead to a loss of legitimacy" (Santos, 2012: 338). According to Santos, the 
problem is that current markets often exclude the poor precisely because the added costs and externalities of serving this population make it difficult for for-profit firms to capture value. Thus while commercial firms may start out targeting the poor, they are likely to migrate to higher-income market segments over time.

In the sections below, I draw on these competing arguments about the risks and benefits of commercialization to develop a set of hypotheses about the relative effectiveness of for-profit and non-profit firms in achieving the goal of market inclusivity. First, I review the social entrepreneurship literature to devise a hypothesis that allows for a direct empirical test of the effect of commercialization on mission drift. I then develop a multilevel, institutional framework to compare this relationship in countries around the world. These hypotheses embed entrepreneurial actions within the national context and suggest that the efficacy of commercial ventures in achieving desired social outcomes on a large scale may depend on the country where these actions occur.

\section{Commercialization and Inclusive Markets}

The first hypothesis draws on mission drift research in the social entrepreneurship literature (Agafonow, 2014; Kent \& Dacin, 2013; Mair, Battilana, \& Cardenas, 2012). Studies on the pressures that encourage mission drift identify multiple mechanisms that help explain why commercially oriented firms may pursue more affluent and advantaged customers even if the company's stated mission is to serve a less privileged customer base. For instance, poorer customers tend to have less regular income streams and erratic purchasing patterns, are more vulnerable to external shocks - such as natural disasters - and are often less sophisticated consumers than wealthier clients (Battilana \& Dorado, 2010; Ebrahim et al., 2014; Prahalad \& Hammond, 2002; Santos, 2012; Santos et al., 2015). These factors often require that firms invest in entirely new marketing campaigns, organizational designs, and distribution channels when working with the poor (Battilana \& Dorado, 2010; Dees \& Anderson, 2003; Santos, 2012).

Research on business and poverty has also found that poor customers tend to live in environments characterized by less developed market institutions. Thus the costs involved in reaching poor individuals are likely to be higher than the costs of serving the wealthy, who have access to a more developed market infrastructure (Battilana \& Dorado, 2010; London \& Hart, 2004; Prahalad, 2005; Simanis, 2012). For instance, Prahalad and Hammond (2002) showed that the costs of basic goods and services such as credit, phone calls, medication, and water were as much as 53 times higher in the shantytowns of India, where needed infrastructure was missing, than in the upper-class suburbs, where such infrastructure was in place and working well. Similarly, Ault and Spicer's (2014) empirical analysis of commercial microfinance around the world reveals that the weak provisioning of property rights protection, security, and rule of law in low-income markets increases the institutional hazards of servicing poorer customers, which reduces the attractiveness of low-income markets to microfinance institutions.

In their grounded case study of the Bangladeshi social enterprise BRAC, Mair et al. (2012) identified a number of theoretical mechanisms to explain the link between unsupportive market institutions and the relative cost of servicing the poor and other disadvantaged populations, such as women. For instance, they note that the Bangladeshi legal codes explicitly guaranteed equal property rights protection to all citizens, but because of the weaknesses in the judiciary system, access to this protection was often available only to wealthy male citizens, who could afford to bribe judicial authorities. They also found that while Bangladesh's constitution may have guaranteed universal economic autonomy, conflicting local legislation often forced the poor into patrimonial relationships with wealthy benefactors, thereby limiting their free market participation. Before setting up social enterprises to deliver dairy, poultry, iodized salt, and other products to the poor, BRAC first had to develop programs to overcome the uneven application of property rights and autonomy. For example, it offset weak property rights protection by providing legal literacy courses and legal assistance to help the poor navigate the complex court system; and when BRAC recognized that interrupted education was a major obstacle to economic autonomy, it established a primary school.

Given the relative costs this venture incurred in its attempts to serve poor clients, it is perhaps not coincidental that BRAC adopted a non-profit governance structure. Had it been a commercial venture, it may have felt pressure to prioritize profits, and it may have been less inclined to take on the extra cost of developing these experimental pilot programs.

Santos (2012) succinctly summarizes these findings and in doing so provides the foundation for the first hypothesis of this study. He posits that if a commercial venture and a non-profit venture both operate in the same industry, providing the same goods or services to the clientele, the commercial venture will 
be more likely to pursue the higher margins of more affluent clients and will migrate to that population over time, leaving low-income populations as the domain of the non-profit venture. This reasoning leads to the following hypothesis:

Hypothesis 1: Over time, mission drift away from the goal of market inclusivity will be greater for for-profit social ventures than for non-profit social ventures.

\section{Institutional Context}

It is already well established that institutions shape incentive structures in ways that influence the degree and type of entrepreneurship in a particular location (Bowen \& De Clercq, 2008; Busenitz et al., 2000; Casper, 2000; Nasra \& Dacin, 2010; Spicer et al., 2000). Yet researchers have only recently begun to explore the implications of this finding in the context of the world's poorest markets (Ault \& Spicer, 2014; Branzei \& Abdelnour, 2010; Bruton, Ahlstrom, \& Obloj, 2008; Hiatt \& Sine, 2014; Kiss, Danis, \& Cavusgil, 2012). Nevertheless, this recent scholarship has important implications for comparative research on the effects of institutions on entrepreneurial action in this context. This section builds on this research to explore how national differences impact the relationship between commercial ownership and mission drift away from the goal of market inclusivity.

As established above, the costs and externalities of providing services to the poor are often high relative to the costs of providing service to the wealthy. This puts pressure on commercial ventures to move into high-end market segments to boost their profits. International entrepreneurship research on lowincome markets extends this argument by suggesting that the intensity of this pressure may depend on national context (Ault \& Spicer, 2014; Bruton et al., 2008; Kiss et al., 2012). While the relative costs of providing services to the poor and providing services to the wealthy may differ sharply in some countries (thus accentuating the risk of mission drift for commercial firms), this difference may be less pronounced in other countries (thus reducing the pressure on commercial firms to move from one segment to the other to maintain profitability).

As an illustration, consider Mair et al.'s (2012) discovery that the weak provisioning of property rights protection and economic autonomy in Bangladesh increased BRAC's costs of serving the poor relative to the costs of serving the wealthy, as BRAC had to first develop programs to overcome a weak market infrastructure. From this example, we can infer that, had Bangladesh possessed stronger market-supporting institutions, there would have been less need for BRAC to develop these initiatives on its own. This would have reduced BRAC's costs of extending market opportunities to the poor. In this scenario, BRAC may have had less need for a nonprofit orientation in order to ensure that it remained focused on its core mission. On the other hand, had the Bangladeshi institutions been even weaker - or non-existent - BRAC may have had to make an even greater investment in market infrastructure in order to reach the poor. In this type of failed state, even a non-profit enterprise such as BRAC might not be able to reach the country's poorest inhabitants.

Recent work on the concept of state fragility provides an important framework for extending Mair et al.'s (2012) argument across national borders. Ault and Spicer (2014) define "state fragility" as the degree to which state power is unable and/or unwilling to fulfill core government functions for the majority of its people, including the poor. These authors used the concept to explore how the national context impacted the institutional hazards of transferring the commercial microfinance business model across the world's poorest countries. They found that countries characterized by high levels of state fragility increased lender operating costs and decreased capacity to raise capital.

Ault and Spicer's (2014) work supports and extends Mair et al.'s (2012) arguments about the impact of institutions on the relative costs of serving the poor. For instance, Ault and Spicer's research also demonstrates the importance of property rights and autonomy protection in facilitating entrepreneurial action in low-income markets. However, they also identify additional factors - such as the ability of governments to control violence and to enact a strong rule of law - as important aspects of state fragility that influence the costs of serving the poor. For example, Ault and Spicer (2014) show that the breakdown of national security institutions in fragile states leads to intense competition by informal actors for the same low-income clients. Because informal individuals play by a different set of rules, they are often more competitive and can force formal, legitimate entrepreneurs out of the marketplace. Moreover, the lack of a strong rule of law in fragile states forces any entrepreneur that serves the poor to invest an inordinate amount of resources in staying formal (see also De Soto, 1989), thus reducing the entrepreneur's ability to extract profits from low-income markets. 
The argument that institutional contexts moderate the effect of commercialization on mission drift resonates with the basic findings in international entrepreneurship on how the processes and outcomes of entrepreneurship differ across borders (Bowen \& De Clercq, 2008; Busenitz et al., 2000; Jones et al., 2011; Kiss \& Danis, 2008). Analyses of national differences in entrepreneurial systems have demonstrated that institutions contribute to both the levels and the profitability of entrepreneurship (Busenitz et al., 2000; Jones et al., 2011; Stephan, Uhlaner, \& Stride, 2015), as well as the strategies and outcomes of entrepreneurial activity across nations (Bowen \& De Clercq, 2008). On the relative efficacy of commercial vs non-profit means of achieving social entrepreneurial goals, an international entrepreneurship perspective cautions against the universal argument that commercially oriented ventures will have the same impact on society, regardless of the situation. Instead, this comparative framework suggests that the social consequences of commercial ventures may differ depending on the national institutional systems in which they are embedded.

Ault and Spicer (2014) were primarily interested in the impact of state fragility on the financial performance of entrepreneurs in low-income markets. But an international social entrepreneurship framework also suggests that this measure is likely to have both a direct effect on mission drift away from market inclusivity and a moderating effect that explains the relative difference of commercial and non-profit ventures in the pursuit of an inclusive-market strategy. The direct effect recognizes that all socially oriented ventures may find it more challenging to reach the poor in fragile states, and may ultimately shift to wealthier clients over time. The moderating effect incorporates the finding in social entrepreneurship research that commercial firms must prioritize value capture, thus making them more sensitive to the effect of institutions on the cost differential between wealthy and poor clients. This leads to the following hypotheses:

Hypothesis 2: The greater the level of state fragility in a country, the greater the level of mission drift away from the goal of market inclusivity in that country over time.

Hypothesis 3: State fragility will positively moderate the relationship between profit status and mission drift away from the goal of market inclusivity, such that mission drift will be greater for for-profit ventures in countries with higher levels of state fragility.

\section{METHODS}

\section{Research Context: Microfinance}

This study tests the three hypotheses through a longitudinal, multilevel analysis that looks at the firmlevel effects of commercialization and national-level effects of state fragility on the degree to which microfinance lenders drift away from the goal of market inclusivity over time. "Microfinance" refers to a model of provisioning small loans to the poor (Ault \& Spicer, 2014; Bruton, Khavul, \& Chavez, 2011; Khavul, 2010). Social entrepreneurship authors and development agencies have identified microfinance as a global industry that has adopted the goal of market inclusivity by extending the benefits of global financial markets to the poor and other marginalized groups that have traditionally been excluded from these opportunities (Kent \& Dacin, 2013; Mair et al., 2012; Mendoza \& Thelen, 2008; UNDP, 2010, 2016). Microfinance now serves almost 100 million poor borrowers in more than 100 developing countries worldwide (MIX, 2015).

An early split in the industry into for-profit and nonprofit lenders (Morduch, 2000) provides a unique opportunity to observe the relative differences in the performance of each type of venture in its pursuit of market inclusivity. While most lenders initially utilized a non-profit model that relied on donations and grants for funding, some organizations realized that demand for small loans was growing faster than their ability to secure donations. They began to explore the possibility of commercialization as a way to raise additional funding (Accion, 2016). In 1992, the development agency Accion International transitioned one of its affiliates, BancoSol in Bolivia, into a commercial business that would pay dividends high enough to attract commercial investments. In 1994, BancoSol began selling microloan-backed securities to investors in the United States; and in 1997, it issued its first dividend of US\$0.45 per share on $\$ 1.1$ million in profits. Accion soon began to transition other partners to the commercial model. In 2007, it brought its Mexican affiliate, Compartamos Banco, through the industry's first IPO, raising over $\$ 400$ million (CGAP, 2007; MicroCapital, 2008).

Similar commercial experiments were also taking place in South Asia. In 1998, social entrepreneur Vikram Akula launched SKS Microfinance in India. By 2005, SKS had earned enough revenue to seek venture capital. In 2006, Akula sold 34\% of SKS to Sequoia Capital, one of Silicon Valley's most prestigious venture capital firms, for $\$ 11.5$ million (Akula, 2011). In 2010, SKS became the industry's 
second IPO, raising \$344 million from prominent investors such as George Soros, Morgan Stanley, and J.P. Morgan (Chen, Rasmussen, Reille, \& Rozas, 2010). Commercialization soon spread through the industry, rapidly extending financial services around the globe. By 2013, roughly $60 \%$ of all borrowers were receiving their loans from commercial lenders (MIX, 2015).

Yet while commercialization has facilitated rapid scaling, it also raises questions about whether forprofit lenders are pursuing the same objectives as their non-profit equivalents. Some observers have argued that commercialization has pushed microfinance lenders "upstream" to provide loans for higherend goods - such as flat-screen TVs, sound systems, and cameras - to the middle classes (Bloomberg Business, 2007). The analysis presented below tests this claim over time and around the world to generalize more broadly about the degree to which nonprofit and commercial entrepreneurial ventures are able to pursue the goal of market inclusivity. The first hypothesis introduced in this study would find support if for-profit commercial microfinance lenders are shown to lend to a significantly wealthier client base than non-profit lenders. The second and third hypotheses would find support if this difference is shown to be affected by national levels of state fragility.

\section{Sample}

All microfinance data used in this analysis are from the Microfinance Information Exchange (MIX, 2015), which scholars have identified as the most accurate and reliable collection of data on the microfinance industry (Ault \& Spicer, 2014; Khavul, 2010). The data set used included data from 2679 lenders in 123 countries. While the study covered 15 years, from 1999 to 2013, the average lender lifespan was 5.88 years. Therefore the final sample included 15,752 unique observations $(2679$ lenders $\times 5.88$ years).

\section{Dependent Variable}

To determine the degree to which microfinance lenders advanced the goal of building inclusive markets for the poor, the study used the most common measure for mission drift in the microfinance literature: "Average Loan Balance per Borrower/GNI per Capita" (Armendariz \& Szafarz, 2011; Battilana \& Dorado, 2010; Cull \& Morduch, 2007; Gonzalez-Vega \& Villafani-Ibarnegaray, 2011; Mersland \& Strøm, 2010; Serrano-Cinca \& GutiérrezNieto, 2014). Various scholars have proposed this measure as a useful proxy for the borrowers' wealth, based on the logic that richer clients can afford larger loans than poorer clients (Mersland \& Strøm, 2010). The study followed the precedent in the literature of dividing loan size by GNI per capita, which standardizes the measure for more accurate cross-national comparisons (Gonzalez \& Meyer, 2009).

\section{Independent Variables}

\section{Commercialization}

MIX identifies each lender as either for-profit or nonprofit based on legal registration. I assigned all nonprofits a value of 0 and all for-profits a value of 1 .

\section{State fragility}

Following Ault and Spicer (2014), the study operationalized state fragility using Kaufmann, Kraay, \& Mastruzzi's (2013) six "Worldwide Governance Indicators:" (1) Voice and Accountability; (2) Political Stability and Absence of Violence; (3) Government Effectiveness; (4) Regulatory Quality; (5) Rule of Law; and (6) Control of Corruption. Ault and Spicer (2014: 1827) recommend the Kaufmann data set over other fragility measures "because it has gone through the most rigorous tests for reliability and validity of the measures commonly used to capture similar concepts of state capability."

Ault and Spicer (2014) suggest combining the six dimensions into a single measure since they are all indicators of the multidimensional state fragility factor. Before following this advice, however, I ran a confirmatory factor analysis on the 2013 measures. This analysis produced a CFI of 0.98 and an SRMR of 0.02 , suggesting a strong fit. ${ }^{2}$ Moreover, tests of the hypotheses that a relationship exists between each observed variable and the underlying state fragility construct were significant at 0.99 confidence levels, thus indicating the presence of a single factor.

Microfinance is found almost exclusively in less developed countries. This fact caused the Kaufmann measure to skew left. I tested for the possibility of a non-normal distribution by running the model with both the raw state fragility scores and the logarithmic transformation of these scores. ${ }^{3}$ The transformed variable significantly improved the model fit $(p<0.05)$. The analysis therefore used this transformation. For ease of interpretation, the model reverse-codes the measure: a higher score on the Kaufmann measure indicates a more capable state; in this study, a higher number indicates a more fragile state. 


\section{Control Variables}

\section{National level}

The first two controls were for the size of the national microfinance market. Larger markets may create economies of scale and reduce the costs of serving the poor. To capture this, the analysis included a log of the country's population (to capture the number of people in the market) and GNI per capita (to capture their relative income). Both measures came from the World Bank's "World Development Indicators" (WDI) (World Bank, 2013).

Next, the study controlled for the national level of urbanization, which was also sourced from the WDI indicators. Servicing the poor in rural areas is likely to create additional costs for the microfinance lender (Cull, Demirgüç-Kunt, \& Morduch, 2011).

The analysis also controlled for economic openness using "openness to trade" from the World Bank's "Doing Business Database" (Doing Business, 2013). Greater government intervention may also increase the cost of serving the poor (Cull et al., 2011).

The next two country-level controls captured the degree of competition from other actors. Competition from traditional banks may push microfinance lenders into poorer markets; I thus included the World Bank's measure of domestic credit provided by the banking sector, as a percentage of GDP. In contrast, competition from aid agencies may push microfinance into wealthier segments; I thus included a measure for "Net Official Development Assistance Received per Capita, Current US\$" from the WDI data base.

The final country-level control was the number and magnitude of civil events, which came from the "Total Summed Magnitude of All Societal Major Episodes of Political Violence" measure in the Polity IV database (Marshall, Gurr, \& Jaggers, 2013). Ault and Spicer (2014) recommend this control for studies that include the effects of state fragility in order to capture the possibility of sudden changes in a country's fragility score over time.

\footnotetext{
Firm level

All firm-level controls came from the MIX (2015) data set. First, the study controlled for the lender's dependence on shareholders for capital. Commercial lenders with access to other sources of capital may feel less pressure to maximize shareholder value, and may be less inclined to drift away from serving the poor. The model thus included two alternative sources of capital: savings accounts (as indicated by
}

the log of the lender's total savings deposits) and debt (captured by the lender's debt-to-equity ratio).

Next, the study controlled for progressive lending, one of the most common alternative hypotheses (other than mission drift) for why lenders might give out larger loans (Armendariz \& Szafarz, 2011). In microfinance, lenders may extend small loans initially, and then give progressively larger loans as clients demonstrate responsible borrowing. Older lenders may therefore provide larger loans without necessarily drifting from the goal of market inclusivity. MIX includes an age indicator (new, young, mature), which I used to create a dummy for lender age.

The study also included two controls for lender size: total assets and total personnel. Finally, the model included lender fixed effects; the thousands of organizations in the sample may each possess idiosyncrasies that impact mission drift.

\section{Robustness Checks}

While average loan size may be the most common measure in microfinance for mission drift away from market inclusivity (Copestake, 2007; Mersland \& Strøm, 2010), there have been few empirical tests of the variable's measurement validity (Armendariz \& Szafarz, 2011). The study therefore added three robustness checks to ensure that the results were not sensitive to the measure of mission drift. The first two have also been used in the microfinance literature to capture mission drift, albeit less frequently than average loan size (Mersland \& Strøm, 2010). The first of these is "Percent of Female Borrowers." In developing countries, women are often excluded from traditional market systems. A lender that shifts to male clients may therefore be migrating away from a development goal of market inclusivity (Mair et al., 2012). The second measure sometimes found in the literature is loan delinquencies. Mendoza and Thelen (2008) point out that serving low-income populations may not be sufficient to advance the goal of market inclusivity if the poor then become worse off. In microfinance, delinquencies have been proposed as a way to determine whether market activity is beneficial (Cull, Demirgüç-Kunt, \& Morduch, 2009). I captured this variable using the MIX measure "portfolio at risk $>90$ days." Third, I combined all three variables (loan size, percentage of female borrowers, and delinquencies) into a single measure of mission drift.

The study also included a robustness check for state fragility, running the model with and without a variable for the country's microfinance regulations. The preference for state fragility in this study, rather than regulatory codes, was based on Ault and 
Spicer's (2014) observation that legal frameworks are often less useful for making meaningful predictions in low-income settings. Ault and Spicer (2014) note that even if a particular law exists, there is no guarantee it will be followed or enforced (see also Portes \& Haller, 2005). They proposed state fragility as a more reliable institutional indicator that captures the underlying capability of the state to create and enforce effective regulations. To test this claim, I ran the model both with and without the Economist Intelligence Unit's (2013) "Global Microscope on the Microfinance Business Environment." This index includes a small number of countries relative to the overall sample (55 vs 123), which significantly hurt the model fit when the measure was included. ${ }^{4}$ The model therefore did not use the measure as a control in the primary analysis, but added it as a robustness check.

\section{Data Analysis}

The analysis used random coefficient modeling (RCM) for multiple reasons. First, the international business literature has specifically identified RCM as an appropriate technique for testing multilevel theories that look at cross-level interactions between firm and national effects (Hitt, Beamish, Jackson, \& Mathieu, 2007; Peterson, Arregle, \& Martin, 2012). Second, RCM can be adapted to capture change over time by inserting a dummy variable for time as the first level of the model and then testing how the predictor variables impact the variance in the relationship between time and the dependent variable (Ployhart, 2005). This method is therefore well suited for analyzing mission drift, a long-term process that occurs over time (Battilana \& Dorado, 2010; Ebrahim et al., 2014). Finally, I tested the relative fit of RCM compared with OLS regression using a likelihood ratio test (critical $X^{2}$ with $3 d f=7.82$ ). This test was significant $(p<0.001)$, which further supported the choice of RCM for this analysis.

The longitudinal RCM used in this study followed Ployhart's (2005: 813) "model-building sequence for hierarchical models." The first step in the sequence was to estimate a simple equation of the dependent variable on time, without taking into account firmor country-level effects. This step established a baseline statistic to determine whether subsequent steps improved the model fit. Because RCM is a maximum likelihood estimation method, it uses -2 Log Likelihood (-2LL) to measure model fit. The baseline likelihood for this analysis was 118,349.64.

The second step in the sequence was to allow the intercept and slope of the regression equation estimated in the first step to become random effects. Significant reductions in the -2LL indicate that the effects of time are nested in the firm and national levels of analysis. This step reduced the likelihood to $113,313.10$, an improvement of 5036.54, which was statistically significant $(p<0.001)$. The third step was to determine the error structure of the model. Taking the log of loan size reduced the likelihood to 10,694.37, an improvement of 102,618.74, which was significant $(p<0.001)$. The transformed dependent variable was thus incorporated into the model. I also tried controls for autoregressive, unstructured, and other error structures. However, in these attempts, the model failed to converge; alternative error structures were therefore not incorporated in the final model. The final step was to add the individual predictor variables into the model - first the control variables and then the hypothesized variables.

\section{RESULTS}

Table 1 presents the descriptive statistics and correlation matrices. Due to the size of the matrix, the table is divided into two sections. Table 1a includes all the independent variables, while Table $1 \mathrm{~b}$ includes the year-over-year correlations for average loan size. Table $1 \mathrm{~b}$ indicates high year-over-year correlations. The RCM literature notes that this is common in longitudinal analysis, since the effects of time are nested in firm and country (Ployhart, 2005). As noted previously, however, controls for alternative error structures failed to converge and were thus not incorporated into the analysis.

Table 2 presents the results of the RCM. Model 1 presents the baseline test of time on mission drift. Model 2 shows the control variables, and Model 3 presents the hypothesis tests.

The first hypothesis predicts that commercialization will increase the risk of mission drift away from market inclusivity. As shown in Table 2, the interaction effect of time $\mathrm{X}$ profit status was positive and significant $(b=0.03 ; p=0.05)$, thus providing support for the hypothesis. ${ }^{5}$ The second hypothesis predicts that state fragility will also increase the risk of mission drift away from market inclusivity over time. As shown in Table 2, the effect of state fragility on the growth of average loan size was positive and significant $(b=0.04 ; p=0.01)$; this hypothesis was therefore also supported. The third hypothesis predicts that state fragility will magnify the relationship between for-profit status and mission drift. As shown in the table, the effects of the interaction between state fragility and profit status on the growth in average 


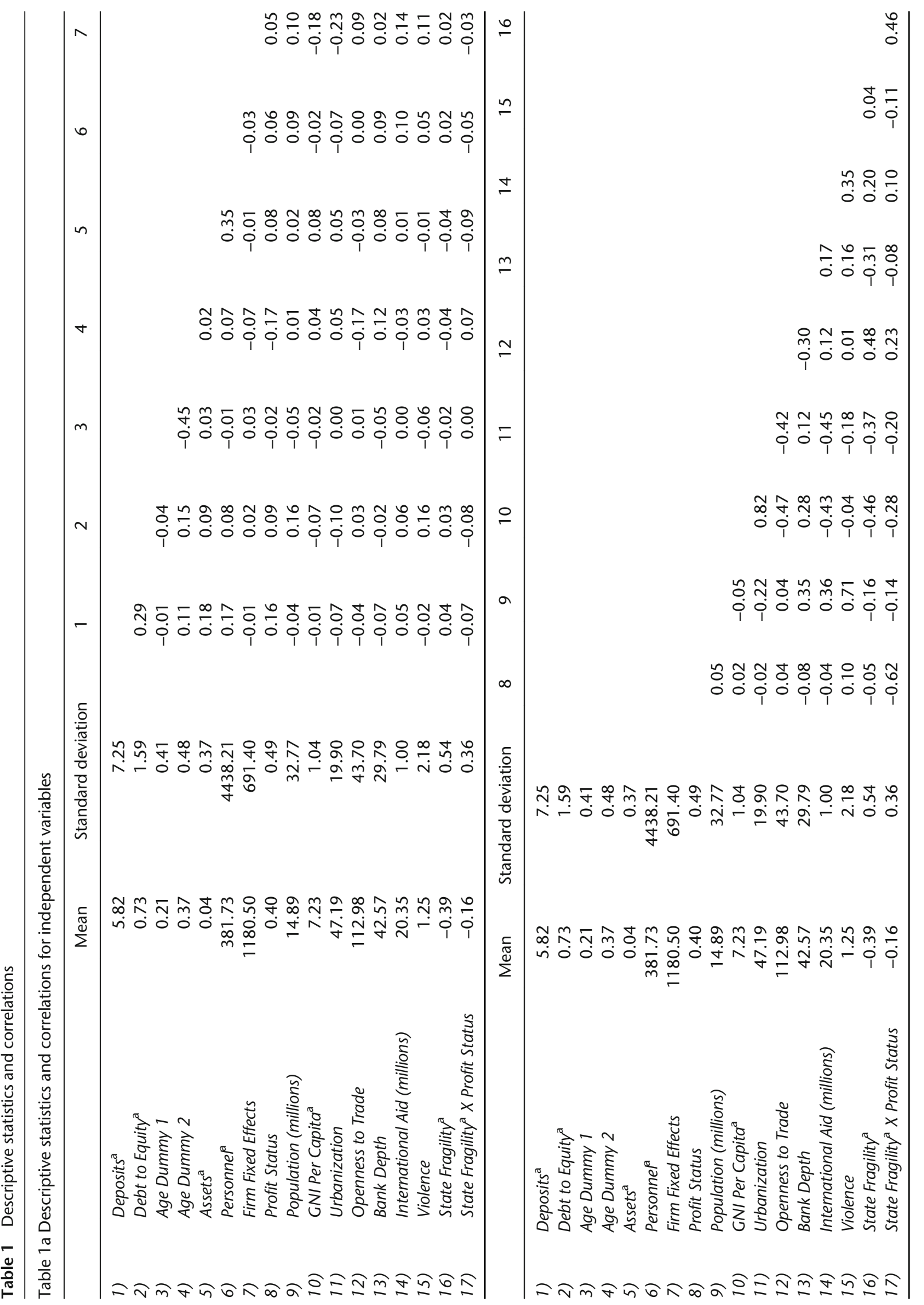







Table 2 Multilevel random coefficient model predicting microfinance mission drift

\begin{tabular}{|c|c|c|c|c|c|c|c|c|c|}
\hline & \multicolumn{3}{|c|}{ Model 1} & \multicolumn{3}{|c|}{ Model 2} & \multicolumn{3}{|c|}{ Model 3} \\
\hline & Coeff. & Std. Error & $z$ - value & Coeff. & Std. Error & $z$-value & Coeff. & Std. Error & $z$-value \\
\hline \multicolumn{10}{|l|}{ SINGLE-LEVEL EFFECTS } \\
\hline \multicolumn{10}{|l|}{ Level 1 (Time) } \\
\hline Time & 0.00 & 0.00 & 0.24 & 0.05 & 0.07 & 0.81 & 0.09 & 0.07 & 1.40 \\
\hline \multicolumn{10}{|l|}{ Level 2 (Firm) } \\
\hline Deposits ${ }^{a}$ & & & & 0.01 & 0.00 & $12.13^{* * *}$ & -0.03 & 0.01 & $-1.91 \dagger$ \\
\hline Debt to Equity ${ }^{a}$ & & & & 0.04 & 0.00 & $9.90^{* * *}$ & 0.06 & 0.01 & $5.69^{* * *}$ \\
\hline Age 1 (Young) & & & & 0.00 & 0.01 & 0.03 & 0.12 & 0.03 & $4.08^{* * *}$ \\
\hline Age 2 (Young) & & & & 0.03 & 0.01 & $2.94^{* *}$ & 0.15 & 0.03 & $5.41^{* * *}$ \\
\hline Assets $^{a}$ & & & & 0.20 & 0.03 & $5.82^{* * *}$ & 0.46 & 0.11 & $4.02^{* * *}$ \\
\hline Personnel $^{\mathrm{a}}$ & & & & -0.01 & 0.00 & $-2.53^{*}$ & -0.02 & 0.01 & $-2.25^{\star}$ \\
\hline Firm Fixed Effects & & & & -0.02 & 0.00 & $-3.82^{\star \star \star}$ & -0.04 & 0.01 & $-2.82^{\star *}$ \\
\hline Profit Status & & & & & & & -0.01 & 0.14 & -0.05 \\
\hline \multicolumn{10}{|l|}{ Level 3 (Country) } \\
\hline Population (millions) & & & & -0.01 & 0.01 & $-2.04^{\star}$ & 0.00 & 0.00 & -1.43 \\
\hline GNI Per Capita ${ }^{a}$ & & & & -0.16 & 0.02 & $-10.31^{* * *}$ & -0.15 & 0.04 & $-4.24^{* * *}$ \\
\hline Urbanization & & & & 0.03 & 0.01 & $4.90^{* * *}$ & 0.00 & 0.00 & 0.50 \\
\hline Openness to Trade & & & & 0.01 & 0.00 & $5.59 * * *$ & 0.01 & 0.01 & $1.87 \dagger$ \\
\hline Bank Depth & & & & -0.01 & 0.00 & $-3.60^{\star \star *}$ & -0.02 & 0.01 & $-2.84^{\star \star}$ \\
\hline International Aid (millions) & & & & -0.03 & 0.01 & $-3.51^{* * *}$ & -0.02 & 0.02 & -0.71 \\
\hline Violence & & & & -0.02 & 0.01 & $-2.85^{\star *}$ & -0.04 & 0.01 & $-2.59 * *$ \\
\hline State Fragility ${ }^{a}$ & & & & & & & -0.37 & 0.14 & $-2.64^{\star *}$ \\
\hline \multicolumn{10}{|l|}{ CROSS-LEVEL EFFECTS } \\
\hline \multicolumn{10}{|l|}{ Country/Organization } \\
\hline State Fragility ${ }^{a} X$ Profit Status & & & & & & & -0.24 & 0.16 & -1.51 \\
\hline \multicolumn{10}{|l|}{ Organization/Time } \\
\hline Time X Deposits ${ }^{\mathrm{a}}$ & & & & 0.01 & 0.00 & $6.21 * * *$ & 0.01 & 0.00 & $6.09^{* * *}$ \\
\hline Time X Debt to Equity ${ }^{a}$ & & & & -0.03 & 0.01 & $-2.31^{*}$ & -0.03 & 0.01 & $-2.10^{*}$ \\
\hline Time X Age 1 (Young) & & & & -0.01 & 0.00 & $-4.05^{\star * *}$ & -0.01 & 0.00 & $-3.74^{* * *}$ \\
\hline Time X Age 2 (Mature) & & & & -0.01 & 0.00 & $-4.26^{* * *}$ & -0.01 & 0.00 & $-3.75^{* * *}$ \\
\hline Time $X$ Assets ${ }^{a}$ & & & & -0.04 & 0.01 & $-3.85^{\star * *}$ & -0.04 & 0.01 & $-3.40^{* * *}$ \\
\hline 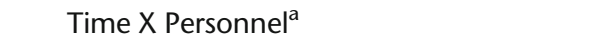 & & & & 0.02 & 0.01 & $1.85 \dagger$ & 0.02 & 0.01 & $1.87 \dagger$ \\
\hline Time $X$ Firm Fixed Effects & & & & 0.00 & 0.00 & 1.32 & 0.00 & 0.00 & 1.41 \\
\hline Time $X$ Profit Status & & & & & & & 0.03 & 0.02 & $1.98^{*}$ \\
\hline \multicolumn{10}{|l|}{ Country/Time } \\
\hline Time X Population (millions) & & & & 0.00 & 0.00 & 0.08 & 0.00 & 0.00 & 0.60 \\
\hline Time X GNI Per Capita ${ }^{a}$ & & & & 0.00 & 0.00 & -0.79 & 0.00 & 0.00 & -0.52 \\
\hline Time X Urbanization & & & & 0.00 & 0.00 & 1.48 & 0.03 & 0.02 & $1.78 \dagger$ \\
\hline Time X Openness to Trade & & & & 0.01 & 0.01 & $1.70 \dagger$ & 0.00 & 0.00 & 0.05 \\
\hline Time X Bank Depth & & & & 0.00 & 0.00 & 1.20 & 0.00 & 0.00 & 1.44 \\
\hline Time X International Aid (millions) & & & & 0.00 & 0.00 & -0.97 & 0.00 & 0.00 & -0.98 \\
\hline Time $X$ Violence & & & & 0.03 & 0.02 & $1.78 \dagger$ & 0.00 & 0.00 & 1.12 \\
\hline Time X State Fragility ${ }^{a}$ & & & & & & & 0.04 & 0.02 & $2.56^{*}$ \\
\hline \multicolumn{10}{|l|}{ Country/Organization/Time } \\
\hline Time $X$ State Fragility ${ }^{a} X$ Profit Status & & & & & & & 0.04 & 0.02 & $2.26^{*}$ \\
\hline Constant & 0.47 & 0.02 & $22.98^{* * *}$ & 1.99 & 0.25 & $7.81^{* * *}$ & 1.22 & 0.55 & $2.21^{\star}$ \\
\hline -2 Log Likelihood & \multicolumn{3}{|c|}{$12,386.69$} & \multicolumn{3}{|c|}{7536.03} & \multicolumn{3}{|c|}{7328.73} \\
\hline Wald $X^{2}$ & \multicolumn{3}{|c|}{0.81} & \multicolumn{3}{|c|}{$1119.23^{* * *}$} & \multicolumn{3}{|c|}{$1402.17^{\star * *}$} \\
\hline
\end{tabular}

Notes: Hypothesized effects are in bold; ${ }^{*} p<0.05 ;{ }^{* *} p<0.01 ;{ }^{* *} p<0.001 ; \dagger p<0.10$.

aLogarithmic transformation. 
Table 3 Loan balance per borrower/GNI per capita for 20 most and 20 least fragile states ${ }^{\mathrm{a}}$

\begin{tabular}{|c|c|c|c|}
\hline $\begin{array}{l}20 \text { Developing Countries with } \\
\text { Most Fragile States }^{a}\end{array}$ & $\begin{array}{l}\text { Loan Balance per Borrower/ } \\
\text { GNI per Capita }{ }^{\text {b }}\end{array}$ & $\begin{array}{l}20 \text { Developing Countries } \\
\text { with Least Fragile States }{ }^{a}\end{array}$ & $\begin{array}{l}\text { Loan Balance per Borrower/ } \\
\text { GNI per Capita }{ }^{b}\end{array}$ \\
\hline Afghanistan & 1.83 & Zambia & 1.02 \\
\hline Congo, Democratic Republic of the & 5.77 & Albania & 0.64 \\
\hline South Sudan & 1.49 & Senegal & 0.25 \\
\hline Yemen & 0.27 & Mongolia & 3.01 \\
\hline Zimbabwe & 1.79 & Armenia & 0.52 \\
\hline Tajikistan & 2.06 & Mexico & 0.31 \\
\hline Nigeria & 0.70 & El Salvador & 0.91 \\
\hline Pakistan & 0.25 & Rwanda & 1.28 \\
\hline Burundi & 3.99 & Serbia & 0.34 \\
\hline Haiti & 0.93 & Suriname & 0.16 \\
\hline Cameroon & 2.20 & Brazil & 0.07 \\
\hline Bangladesh & 0.22 & Jamaica & 0.23 \\
\hline Ethiopia & 0.49 & Panama & 0.93 \\
\hline Côte d'Ivoire (Ivory Coast) & 2.56 & Ghana & 1.35 \\
\hline Madagascar & 1.70 & Montenegro & 0.22 \\
\hline Mali & 4.02 & Romania & 0.93 \\
\hline Laos & 1.86 & Georgia & 1.06 \\
\hline Kyrgyzstan & 2.15 & South Africa & 0.15 \\
\hline Liberia & 0.86 & Poland & 0.99 \\
\hline Cambodia & 2.40 & Chile & 0.48 \\
\hline Average & 1.88 & Average & 0.74 \\
\hline
\end{tabular}

${ }^{a}$ Average of the Worldwide Governance Indicators (Kaufmann et al., 2013).

${ }^{\text {b }}$ Source: MIX (2015)

loan size was positive and significant $(b=0.04$; $p=0.02$ ), thus supporting the third hypothesis.

Table 3 illustrates the moderating effect of state fragility on the relationship between commercialization and mission drift in microfinance. This table lists the 20 most fragile states and the 20 least fragile states found in the MIX database, according to the Kaufmann et al. (2013) governance indicators. It then shows the average loan balance per borrower/ GNI per capita for the commercial lenders found in the database for each country in 2013. As shown here, commercial lenders in the most fragile states dispersed loans that were, on average, 1.88 times the average income in that country. In contrast, lenders in the least fragile states dispersed loans that were, on average, 0.74 times the national income level, indicating a poorer client base.

\section{Robustness Checks}

The robustness checks supported the use of average loan size as a measure of mission drift. ${ }^{6}$ When I used "percent female borrowers" in place of loan size, the effect of state fragility and fragility $X$ profit status remained significant at 0.05 significance levels.
When I included "portfolio at risk > 90 days," the effect of profit status and state fragility X profit status both remained significant at 0.05 significance levels. When I combined all three indicators of mission drift into a single factor, profit status and state fragility $\mathrm{X}$ profit status remained significant at 0.01 significance levels. The robustness checks also supported the argument that state fragility, and not legal codes, influence mission drift away from market inclusivity. When the Economist Intelligence Unit's (2013) regulatory frameworks measure was included, profit status and fragility X profit status remained significant at 0.10 significance levels, but neither the "regulations" variable nor regulations $\mathrm{X}$ profit status was significant.

\section{DISCUSSION}

The international social entrepreneurship framework developed in this article makes several contributions to the study of social entrepreneurship and the study of international entrepreneurship. First, the multilevel analysis of lending patterns in a data set of 2679 for-profit and non-profit microfinance lenders in 123 countries over 15 years provides a large-scale, longitudinal empirical test of a key 
debate in the literature about the benefits and risks of commercial methods for advancing the goal of market inclusivity (Agafonow, 2014; London \& Hart, 2011; Prahalad, 2005; Santos, 2012). This analysis shows that for-profit, socially oriented organizations are more likely to drift away from the goal of market inclusivity over time, thus suggesting a limitation to the broad claim that commercial ventures provide the best opportunity for rapidly expanding market opportunities to the billions of poor individuals currently excluded from the global economy (London \& Hart, 2011; Prahalad, 2005).

However, by integrating the international entrepreneurship literature into this debate (Busenitz et al., 2000; Kiss et al., 2012), the study makes a second contribution by introducing an institutional contingency. While commercialization may be a risky strategy for advancing socially desirable goals in many circumstances, under the right conditions, it may be an effective method for reaching scale in the world's poorest markets. In the analysis, less fragile states were shown to provide the institutional conditions that lowered the relative cost of servicing the poor, thus reducing the need for forprofit ventures to migrate into wealthier markets over time to survive. This finding suggests a new way to think about the relationship between forprofit and non-profit social ventures. The current debate focuses on whether for-profit models are more effective than non-profit models in the delivery of needed goods and services to the poor. An international social entrepreneurship perspective suggests the need to find complementarities between the two models and match the appropriate strategy with the location where it is most likely to achieve the desired goals (see Ault \& Spicer, 2010).

The irony highlighted by this finding is that the same fragile states that tend to have the most poverty, and thus the strongest need for commercial methods to reach the poor on a large scale (Prahalad, 2005), also appear to have the greatest differences in the costs of servicing the poor relative to servicing the wealthy. In these locations, there is an increased likelihood that commercial strategies will result in mission drift rather than greater market inclusivity. This finding leads to a series of important questions about whether low-income markets in fragile states can be reached at all through commercial methods, or if moderating conditions exist that will help ventures to work more effectively in hostile institutional environments. For instance, future researchers may wish to explore ways for for-profit ventures to proactively manage the fragile state to prevent mission drift.
The framework developed here also contributes to the international entrepreneurship literature (Busenitz et al., 2000; Jones et al., 2011; McDougall \& Oviatt, 2000). Scholars have begun to recognize that this research tends to focus on the impact of national institutions on the profitability levels of entrepreneurial firms across national boundaries, with less emphasis on the social consequences; they are thus working to address this gap. For instance, Stephan et al. (2015) look at whether supportive institutions would increase the number of social entrepreneurs found in a particular location. Bowen and De Clercq (2008) point out that an important direction for international entrepreneurship research is examining how institutions shape the consequences of the firm's actions after the decision to launch a new venture has been made. The impact of national institutions on the ability of social entrepreneurs to achieve firm-level profitability goals and social measures of success therefore represents an important new research direction.

One limitation to any analysis of low-income markets stems from the challenge of gathering reliable data in developing countries (Kolk et al., 2014). In the current study, this issue was clear in the use of the MIX data. MIX is frequently cited as the most used and most accurate dataset to track the microfinance industry (Ault \& Spicer, 2014; Khavul, 2010). However, in the absence of reliable government data, MIX must rely on self-reporting. This introduces the possibility of reporting bias, where certain types of firms systematically choose not to disclose a variable used in the study (Bauchet \& Morduch, 2009). The longitudinal RCM used in this study provided one solution to the issue. Bliese and Ployhart (2002: 365) state that, "one of the strengths of RCM is that the missing data pose no particular problems in terms of estimation." Since the method compares the lenders that do report to the database to themselves year over year, robust parameters can still be estimated from the available sample. However, subsequent studies may need to look for additional sources of data in order to broaden the applicability of this research.

An additional limitation of the study was the dichotomous classification of social ventures as forprofits and non-profits. Some ventures are beginning to experiment with alternative "hybrid" governance models such as L3C or CIC (Ebrahim et al., 2014). However, the MIX data set does not explicitly identify these legal forms as a category separate from the non-profit/for-profit designation. Future research 
may be necessary to reconcile these new types of corporations with more traditional forms.

A final limitation of the study is its reliance on large-scale empirical analysis, which only considers aggregate data. The results do not suggest that individual firms are simply unable to develop strategies to manage the tension between profits and impact; rather, on average, the pressure to succumb to mission drift is strong in some environments. The current debate in the literature over the power of mission drift suggested a need to test the issue on a large scale. An important task for future research will be to examine individual firms through case analysis in order to identify firm-based strategies that might also influence the relationship between commercialization and mission drift.

Despite these limits, the study contributes to the research by providing a large-scale empirical analysis that applies the international entrepreneurship literature to a research question that has traditionally fallen within the domain of social entrepreneurship. Further research will be necessary to consider all the ways that institutions impact how ventures pursue social goals, but in the meantime this study makes a unique contribution: it suggests that the opportunity to commercialize innovative non-profit models and still serve a similar low-income market segment may be tied to the particular institutional context in which this service is provided.

\section{ACKNOWLEDGEMENTS}

I thank Andrew Spicer, Becky Reuber, and three anonymous reviewers for their insights and guidance throughout this project. Some funding for article preparation and for open-access dissemination was pro-

\section{REFERENCES}

Accion. 2016. Accion's history, www.accion.org/content/our-history, accessed 21 January 2016.

Agafonow, A. 2014. Toward a positive theory of social entrepreneurship: On maximizing versus satisficing value capture. Journal of Business Ethics, 125(4): 709-713.

Agafonow, A. 2015. Value creation, value capture, and value devolution: Where do social enterprises stand. Administration \& Society, 47(8): 1038-1060.

Akula, V. 2011. A fistfull of rice: My unexpected quest to end poverty through profitability. Boston: Harvard Business School Press.

Armendariz, B., \& Szafarz, A. 2011. On mission drift in microfinance institutions. In B. Armendariz, \& M. Labie (Eds), The handbook of microfinance 341-366. Singapore: World Scientific Publishing.

Ault, J. K., \& Spicer, A. 2010. Does one size fit all in microfinance? New directions for academic research. In T. A. Watkins, \& $\mathrm{K}$. Hicks (Eds), Moving beyond storytelling: Emerging research in vided by the Centre for Social and Sustainable Innovation under a donation from Goldcorp Inc. An earlier version of this article received feedback in the Junior Faculty and Doctoral Student Paper Development Workshop on International Entrepreneurship sponsored by CU Denver's CIBER and the Jabs Center for Entrepreneurship, and the Social Sciences and Humanities Research Council of Canada.

\section{NOTES}

${ }^{1}$ The goal of improving financial access for lowerincome customers is also referred to as "financial inclusion" (Dev, 2006; UNDP, 2016). This study will use the more encompassing "market inclusion," which is the term employed in the broader management literature (see Mair et al., 2012).

${ }^{2}$ Researchers also use $X^{2}$ and RMSEA to test fit. However, these measures are sensitive to sample size and are therefore not recommended for samples less than 250 (lacobucci, 2010).

${ }^{3}$ Before taking the log, I added the minimum value to each score to make all values positive.

${ }^{4}$ The inclusion of this variable increased the $-2 \mathrm{LL}$ by $28,326.62$, indicating a poorer fit.

${ }^{5}$ The implication of this coefficient is that, over the 15 years of the study, the typical for-profit firm will migrate to loans that are 1.57 times the size of those offered by non-profits $\left(e^{0.03^{*} 15}\right)$. The combined practical significance of commercialization and state fragility from a cross-sectional perspective is illustrated in Table 3.

${ }^{6}$ After 2011, many lenders stopped reporting "percent female borrowers" and "portfolio at risk," preventing the model from converging when 2012 and 2013 were included. Therefore, robustness checks include the years 1999-2011.

microfinance (contemporary studies in economic and financial analysis, vol. 92): 271-284. Bingley, UK: Emerald Group Publishing.

Ault, J. K., \& Spicer, A. 2014. The institutional context of poverty: State fragility as a predictor of cross-national variation in commercial microfinance lending. Strategic Management Journal, 35(12): 1818-1838.

Battilana, J., \& Dorado, S. 2010. Building sustainable hybrid organizations: The case of commercial microfinance organizations. Academy of Management Journal, 53(6): 1419-1440.

Battilana, J., Lee, M., Walker, J., \& Dorsey, C. 2012. In search of the hybrid ideal. Stanford Social Innovation Review, 10(3): 50-55.

Bauchet, J., \& Morduch, J. 2009. Selective knowledge: Reporting biases in microfinance data. Perspectives on Global Development and Technology, 9(3): 240-269.

Bliese, P. D., \& Ployhart, R. E. 2002. Growth modeling using random coefficient models: Model building, testing, and illustrations. Organizational Research Methods, 5(4): 362-387. 
Bloomberg Business. 2007. The ugly side of microlending, www. bloomberg.com/bw/stories/2007-12-12/the-ugly-side-ofmicrolending, accessed 10 June 2015.

Bowen, H. P., \& De Clercq, D. 2008. Institutional context and the allocation of entrepreneurial effort. Journal of International Business Studies, 39(4): 747-767.

Branzei, O., \& Abdelnour, S. 2010. Another day, another dollar: Enterprise resilience under terrorism in developing countries. Journal of International Business Studies, 41(5): 804-825.

Bruton, G. D., Ahlstrom, D., \& Obloj, K. 2008. Entrepreneurship in emerging economies: Where are we today and where should the research go in the future. Entrepreneurship Theory and Practice, 32(1): 1-14.

Bruton, G. D., Khavul, S., \& Chavez, H. 2011. Microlending in emerging economies: Building a new line of inquiry from the ground up. Journal of International Business Studies, 42(5): 718-739.

Busenitz, L. W., Gomez, C., \& Spencer, J. W. 2000. Country institutional profiles: Unlocking entrepreneurial phenomena. Academy of Management Journal, 43(5): 994-1003.

Casper, S. 2000. Institutional adaptiveness, technology policy, and the diffusion of new business models: The case of German biotechnology. Organization Studies, 21(5): 887-914.

Casper, S., \& Whitley, R. 2004. Managing competences in entrepreneurial technology firms: A comparative institutional analysis of Germany, Sweden and the UK. Research Policy, 33(1): 89-106.

CGAP. 2004. Building inclusive financial systems: Donor guidelines on good practice in microfinance. Washington DC: CGAP/The World Bank.

CGAP. 2007. CGAP reflections on the Compartamos initial public offering, www.cgap.org/publications/cgap-reflections-compartamos-initial-public-offering, accessed 10 June 2015.

Chen, G., Rasmussen, S., Reille, X., \& Rozas, D. 2010. Indian microfinance goes public: The SKS initial public offering. CGAP Focus Note No. 65

Collier, P., \& Dollar, D. 2002. Globalization, growth, and poverty: Building an inclusive world economy. New York: Oxford University Press.

Copestake, J. 2007. Mainstreaming microfinance: Social performance management or mission drift? World Development, 35(10): 1721-1738.

Cull, R., Demirgüç-Kunt, A., \& Morduch, J. 2009. Microfinance tradeoffs: Regulation, competition, and financing. World Bank Policy Research Working Paper 5086.

Cull, R., Demirgüç-Kunt, A., \& Morduch, J. 2011. Does regulatory supervision curtail microfinance profitability and outreach? World Development, 39(6): 949-965.

Cull, R., \& Morduch, J. 2007. Financial performance and outreach: A global analysis of leading microbanks. The Economic Journal, 117(517): F107-F133.

Dacin, P. A., Dacin, T. M., \& Matear, M. 2010. Social entrepreneurship: Why we don't need a new theory and how we move forward from here. Academy of Management Perspectives, 24(3): $37-57$.

De Soto, H. 1989. The other path: The economic answer to terrorism. New York: Harper \& Row.

Dees, J. G., \& Anderson, B. B. 2003. Sector-bending: Blurring lines between nonprofit and for-profit. Society, 40(4): 16-27.

Dev, S. M. 2006. Financial inclusion: Issues and challenges. Economic and Political Weekly, 41(41): 4310-4313.

Doing Business. 2013. Doing business 2013: Smarter regulations for small and medium-size enterprises, 10th edn. Washington DC: World Bank Publications.

Ebrahim, A., Battilana, J., \& Mair, J. 2014. The governance of social enterprises: Mission drift and accountability challenges in hybrid organizations. Research in Organizational Behavior, 34: $81-100$.

George, G., McGahan, A. M., \& Jaideep, P. 2012. Innovation for inclusive growth: Towards a theoretical framework and research agenda. Journal of Management Studies, 49(4): 661-683.
Gonzalez, A., \& Meyer, R. L. 2009. Microfinance and small deposit mobilization: Fact or fiction. MIX Data Brief No. 2.

Gonzalez-Vega, C., \& Villafani-lbarnegaray, M. 2011. Microfinance in Bolivia: Foundation of the growth, outreach and stability of the financial system. In B. Armendariz, \& M. Labie (Eds), Handbook of microfinance 203-250. Singapore: World Scientific Publishing.

Hart, S. L. 2005. Capitalism at the crossroads: The unlimited business opportunities in solving the world's most difficult problems. Upper Saddle River, NJ: Prentice Hall.

Hiatt, S. R., \& Sine, W. D. 2014. Clear and present danger: Planning and new venture survival amid political and civil violence. Strategic Management Journal, 35(5): 773-785.

Hitt, M. A., Beamish, P. W., Jackson, S. E., \& Mathieu, J. E. 2007. Building theoretical and empirical bridges across levels: Multilevel research in management. Academy of Management Journal, 50(6): 1385-1399.

lacobucci, D. 2010. Structural equations modeling: Fit indices, sample size, and advanced topics. Journal of Consumer Psychology, 20(1): 90-98.

Jones, M. V., Coviello, N., \& Tang, Y. K. 2011. International entrepreneurship research (1989-2009): A domain ontology and thematic analysis. Journal of Business Venturing, 26(6): 632-659.

Karnani, A. 2007. The mirage of marketing to the bottom of the pyramid. California Management Review, 49(4): 90-111.

Kaufmann, D., Kraay, A., \& Mastruzzi, M. 2013. Worldwide governance indicators, http://info.worldbank.org/governance/wgi/index.aspx - home, accessed 15 November 2013.

Kent, D., \& Dacin, M. T. 2013. Bankers at the gate: Microfinance and the high cost of borrowed logics. Journal of Business Venturing, 28(6): 759-773.

Khavul, S. 2010. Microfinance: Creating opportunities for the poor. Academy of Management Perspectives, 24(3): 58-72.

Kiss, A. N., \& Danis, W. M. 2008. Country institutional context, social networks, and new venture internationalization speed. European Management Journal, 26(6): 388-399.

Kiss, A. N., Danis, W. M., \& Cavusgil, S. T. 2012. International entrepreneurship research in emerging economies: A critical review and research agenda. Journal of Business Venturing, 27(2): 266-290.

Kolk, A., Rivera-Santos, M., \& Rufín, C. 2014. Reviewing a decade of research on the "base/bottom of the pyramid" (BOP) concept. Business \& Society, 53(3): 338-377.

London, T., \& Hart, S. L. 2004. Reinventing strategies for emerging markets: Beyond the transnational model. Journal of International Business Studies, 35(5): 350-370.

London, T., \& Hart, S. L. 2011. Next generation business strategies for the base of the pyramid: New approaches for building mutual value. Upper Saddle River, NJ: FT Press.

Mair, J., Battilana, J., \& Cardenas, J. 2012. Organizing for society: A typology of social entrepreneuring. Journal of Business Ethics, 111(3): 353-373.

Mair, J., \& Marti, I. 2006. Social entrepreneurship research: A source of explanation, prediction, and delight. Journal of World Business, 41(1): 36-44.

Mair, J., Marti, I., \& Ventresca, M. J. 2012. Building inclusive markets in rural bangladesh: How intermediaries work institutional voids. Academy of Management Journal, 55(4): 819-850.

Marshall, M. G., Gurr, T. R., \& Jaggers, K. 2013. Polity IV project: Political regime characteristics and transitions, 1800-2012. Dataset users' manual, http://www.systemicpeace.org/inscr/ p4manualv2012.pdf, accessed 15 March 2016.

McDougall, P. P., \& Oviatt, B. M. 2000. Entrepreneurship: The intersection of two research paths. Academy of Management Journal, 43(5): 902-906.

Mendoza, R. U., \& Thelen, N. 2008. Innovations to make markets more inclusive for the poor. Development Policy Review, 26(4): 427-458.

Mersland, R., \& Strøm, R. Ø. 2010. Microfinance mission drift? World Development, 38(1): 28-36. 
MicroCapital. 2008. Microcapital story: Compartamos windfall one year later, www.microcapital.org/microcapital-story-compartamos-windfall-one-year-later/, accessed 10 June 2015.

MIX. 2015. The microfinance information exchange, www.mix market.org, accessed 16 March 2015.

Mizik, N., \& Jacobson, R. 2003. Trading off between value creation and value appropriation: The financial implications of shifts in strategic emphasis. Journal of Marketing, 67(1): 63-76.

Morduch, J. 2000. The microfinance schism. World Development, 28(4): 617-629.

Nasra, R., \& Dacin, M. T. 2010. Institutional arrangements and international entrepreneurship: The state as institutional entrepreneur. Entrepreneurship Theory and Practice, 34(3): 583-609.

Peredo, A. M., \& McLean, M. 2006. Social entrepreneurship: A critical review of the concept. Journal of World Business, 41(1): $56-65$.

Peterson, M. F., Arregle, J.-L., \& Martin, X. 2012. Multilevel models in international business research. Journal of International Business Studies, 43(5): 451-457.

Ployhart, R. E. 2005. Hierarchical models. In B. S. Everitt, \& D. Howell (Eds), Encyclopedia of statistics in behavioral science 810-816. London: Wiley.

Portes, A., \& Haller, W. 2005. The informal economy. In N. J. Smelser, \& R. Swedberg (Eds), The handbook of economic sociology 403-428. New York: Russell Sage.

Prahalad, C. K. 2005. The fortune at the bottom of the pyramid: Eradicating poverty through profits. Upper Saddle River, NJ: Wharton School Publishing.

Prahalad, C. K., \& Hammond, A. 2002. Serving the world's poor profitably. Harvard Business Review, 80(9): 48-57.

Ramus, T., \& Vaccaro, A. 2014. Stakeholders matter: How social enterprises address mission drift. Journal of Business Ethics. Advance online publication, doi:10.1007/s10551-0142353-y.

Santos, F. M. 2012. A positive theory of social entrepreneurship. Journal of Business Ethics, 111(3): 335-351.

Santos, P., Pache, A.-C., \& Birkholz, C. 2015. Making hybrids work: Aligning business models and organizational design for social enterprises. California Management Review, 57(3): $36-58$.

Serrano-Cinca, C., \& Gutiérrez-Nieto, B. 2014. Microfinance, the long tail and mission drift. International Business Review, 23(1): $181-194$

Simanis, E. 2012. Reality check at the bottom of the pyramid. Harvard Business Review, 90(6): 120-125.

Spicer, A., McDermott, G. A., \& Kogut, B. 2000. Entrepreneurship and privatization in central Europe: The tenuous balance between destruction and creation. Academy of Management Review, 25(3): 630-649.

Stephan, U., Uhlaner, L. M., \& Stride, C. 2015. Institutions and social entrepreneurship: The role of institutional voids, institutional support, and institutional configurations. Journal of International Business Studies, 46(3): 308-331.
The Economist Intelligence Unit. 2013. Global microscope on the microfinance business environment 2013. London: The Economist Intelligence Unit.

UNDP. 2004. Unleashing entrepreneurship: Making business work for the poor. New York: United Nations Development Programme.

UNDP. 2010. Inclusive markets development handbook. New York: United Nations Development Programme.

UNDP. 2016. What is inclusive finance, www.unpri.org/areas-ofwork/implementation-support/piif/what-is-inclusive-finance/, accessed 20 January 2016.

USAID. 2014. A framework for inclusive market system development, www.microlinks.org/sites/default/files/resource/files/ Market_Systems_Framework.pdf, accessed 22 January 2016.

Walsh, J. P., Kress, J. C., \& Beyerchen, K. W. 2005. Book review essay: Promises and perils at the bottom of the pyramid. Administrative Science Quarterly, 50(3): 473-482.

World Bank. 2013. World development indicators 2013. Washington DC: World Bank Publications.

Zahra, S. A., Newey, L. R., \& Li, Y. 2014. On the frontiers: The implications of social entrepreneurship for international entrepreneurship. Entrepreneurship Theory and Practice, 38(1): 137-158.

Zahra, S. A., Rawhouser, H. N., Bhawe, N., Neubaum, D. O., \& Hayton, J. C. 2008. Globalization of social entrepreneurship opportunities. Strategic Entrepreneurship Journal, 2(2): 117-131.

\section{ABOUT THE AUTHOR}

Joshua K Ault (PhD, University of South Carolina) is an Assistant Professor of International Business at the Gustavson School of Business, University of Victoria. He is interested in the impact of the state on cross-national differences in entrepreneurial outcomes in low-income countries. He is an American citizen and can be reached at jault@uvic.ca.

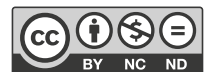

This work is licensed under a Creative Commons Attribution-NonCommercial-NoDerivs 3.0 Unported License. The images or other third party material in this article are included in the article's Creative Commons license, unless indicated otherwise in the credit line; if the material is not included under the Creative Commons license, users will need to obtain permission from the license holder to reproduce the material. To view a copy of this license, visit http://creativecommons. org/licenses/by-nc-nd/3.0/ 